\title{
MAJOR TRENDS AND NEW BUSINESS MODELS IN SUPPLY CHAIN AND ENTREPRENEURSHIP AFTER THE COVID-19 CRISIS
}

\author{
Cristian Negrutiu* \\ Bucharest University of Economic Studies, Bucharest, Romania \\ E-mail: cristian_negrutiu@yahoo.com
}

(Received: October 2020; Accepted: December 2020; Published: January 2021)

\begin{abstract}
The paper investigates the major trends and business models of the new reality after the Covid-19 crisis. Due to the vastness of the theme, the research will be focused on the areas of supply chain and entrepreneurship. These sectors are probably the most affected today, but, also, the ones that will experience a major change in the future. Building on insights and data from top management consultants, the findings revealed some commons trends, like digitization, transparency, localization, the rising of $e$ commerce and the contact-less economy. In conclusion, the author proposes a model based on a virtuous cycle of elements that will shape the business models of the future as a contribution to the research in the selected sectors.
\end{abstract}

Keywords: health crisis; new reality; business models; supply chain; entrepreneurship

JEL Classification: G24, L26, L90, M13, O30

\section{Introduction}

The year 2020 started as a normal year. People and businesses prepared carefully their budgets and begin the execution of the plans, either professionally or personally. At the end of January, there were rumors about a new disease in China, but most of the people in Europe and the US dismissed it as a Chinese problem. However, things gradually picked up and the new coronavirus outbreak in Italy and then to the whole of Europe. Very soon, the disease crosses the Atlantic Ocean and spread into the US. Given the facts, on 11 March 2020, the World Health Organization formally declared COVID-19 a pandemic.

What happens next triggered an unprecedented reality in the recent history of

*Corresponding author: Cristian Negrutiu. E-mail: cristian_negrutiu@yahoo.com

Copyright (C) 2021 The Author(s). Published by VGWU Press

This is an Open Access article distributed under the terms of the Creative Commons BY 4.0 license (Creative Commons - Attribution 4.0 International - CC BY 4.0) which permits unrestricted use, distribution, and reproduction in any medium, provided the original author and source are credited.

84 sciendo Studia Universitatis "Vasile Goldis" Arad. Economics Series Vol 31 Issue 1/2021 ISSN: 1584-2339; (online) ISSN: $2285-3065$

Web: publicatii.uvvg.ro/index.php/studiaeconomia. Pages 84-96 
Negrutiu, C., (2021)

Major trends and new business models in supply chain and entrepreneurship after the Covid-19 crisis

humanity. Of course, we experienced pandemic in the past, but the current level of globalization leads to o global impact. Businesses were shut down instantaneously, people were lockdown and governments switched their agenda to disease containment.

The paper is designed as desk research. It starts with a rapid literature review, followed by the methodology section, where the author will present the arguments for the selected references. The second part features a review and a discussion of the main insights, trends, models presented by the top management consultants selected. The conclusion summarizes the findings and presents an overview of the common ideas. Last, but not least, a model based on a virtuous cycle of elements is proposed.

\section{Literature review}

In the literature, the effects of the previous crisis were deeply analyzed and the lessons learned are useful in the current context. For Hermann (1963) a crisis is an unexpected event that threatens the core values of an organization in a very short period. Furthermore, Mitroff (1988) develops a Theory of Crisis Management Teams, advising organizations to be prepared for a crisis by establishing and consolidating such teams. In addition, Brătianu (2020) insists that crisis management should be embedded in the more general framework of risk and sustainability management. The same holistic approach to risk and sustainability is maintained also by Ciocoiu, Prioteasa, and Colesca (2020).

In the more specific area of the supply chain, Rashad and Nedelko (2020) maintain that a new framework is needed to achieve supply chain sustainability in times of crisis, where the concepts of lean and agile will be re-visited. In contrast, Obrenovic et al (2020) cited resilience as a key pre-requisite of a sustainable supply chain in a time of crisis. The same authors analyze other factors that can help organizations navigate a crisis, like virtuality of processes, the flexibility of culture and distributed leadership and workforce. Entrepreneurial initiatives are the catalyst to new venture creation and growth. Maritz, Perenyi, de Waal, and Buck, (2020) maintain that an entrepreneurial mindset is key for passing successfully a crisis. The authors point also to resilience and leverage the experience of senior entrepreneurs. The trend towards digitalization and the use of artificial intelligence is highlighted by Pelău and Ene (2020). The authors demonstrate that, even human interaction is still preferred in relation to the consumers, younger generations, below 40, have a preference for using new and digitized tools.

In regard to the literature specific to the impact of Covid-19, the studies are quite rare, given the novelty of the topic. Pato and Herczeg (2020) indicate that the impact on supply chains will be severe, maintaining that especially value-added activities will become more important. In this context, key elements like 
Negrutiu, C., (2021)

Major trends and new business models in supply chain and entrepreneurship after the Covid-19 crisis

organizational strategy and inventory levels required attention and re-structuring. From a different perspective, Tecău et al (2020) looked at the impact of Covid-19 on the heavy work investment. Based on statistical analysis, the authors conclude that both components, time and effort, are negatively impacted and recommend the business environment to stimulate the employees to achieve higher performance. Digitization and usage of online can play a pivotal role in this effort and bring significant benefits,

For the purpose of this paper, the author has chosen to research the official publications of large consulting companies. These are reputable sources of thinking, as they are backed by powerful organizations, with a huge amount of data and know-how. The research will look at trends and business models in general, with a particular focus on the areas of supply chain and entrepreneurship. The supply chain was arguably the most affected segment in the current crisis and the need for a re-thinking is a common idea in all studies. On the other hand, every crisis is an opportunity for innovation and for new businesses to be born, therefore the interest in entrepreneurship.

Based on the above considerations, this study attends to bring a new contribution to the existing literature by presenting how theoretical concepts of crisis management, risk and sustainability are put into practice in the context of the Covid-19 health crisis.

\section{Methodology}

The results and discussion will be based on official reports and research of top management consultants. The aim of the review is to compare, contrast and integrate the main views, opinions and trends in order to identify the main strategies for development after the crisis.

It is true that during the crisis and currently on-going, a lot of entities, including international and local organizations, governments, banks, etc, have published reports and studies. However, the author chooses to narrow the research to large management consultants due to their immediate business applicability. Also, the insights provided are backed by a huge amount of real-life data, coming from all industries/sectors. These consultants are in direct and permanent contact with thousands of companies, therefore the data that they use are very rich and up to date, at the same time. As regards to geography, the research interest was focused on Europe, so that's the reason for the selection of the management consultants presented in this paper. According to various reports, these companies are in the top 10 in Europe and all of them are pure consultants, meaning they are not the consulting arm of a Big4 audit firm (e.g. KPMG) or doing consultancy as part of IT projects implementation (e.g. Accenture).

The author selected only studies and insights categorized as research articles by

86 Sciendo Studia Universitatis "Vasile Goldis" Arad. Economics Series Vol 31 Issue 1/2021 ISSN: 1584-2339; (online) ISSN: $2285-3065$

Web: publicatii.uvvg.ro/index.php/studiaeconomia. Pages 84-96 
Negrutiu, C., (2021)

Major trends and new business models in supply chain and entrepreneurship after the Covid-19 crisis

these management consultants. Business articles or other articles and reports were read-only and not presented in this paper. The review was performed on the dedicated research (not commercial) website of the consultants, with the focus on the two selected topics. Also, the review was done cross-articles, meaning that the author selected themes, topics, and ideas from the cited sources of the selected consultants, and then present them in an integrated manner, highlighting commonalities and differences. As such, the reference in the paper is the name of the consultant, as the information was aggregated from the sources that are mentioned in the list of references.

\section{Results and discussion}

In order to group logically the results and to be aligned with the objectives set in the introduction sections, this chapter will be divided into three sub-chapters. In the first one, we will present general trends and business models, while in the second chapter we will discuss more about supply chain and entrepreneurship. The third chapter will describe the business models of the future, having a digital transformation as their cornerstone.

\subsection{Major trends triggered by COVID-19 pandemic}

McKinsey \& Co is the biggest management consulting company in the world and in Europe also. The firm has a consistent and rich research focus and has established itself as an authority in business and management topics. McKinsey has a dedicated page where they provided regular insights, articles and statistics regarding the current health crisis and, most important, how the future will look in their opinion.

McKinsey (2020a) proposed five main categories of research, targeting different angles and aspects generated by the crisis. These categories correspond to a specific stage in dealing with the health crisis and looking forward to the next normal, starting with Resolve, Resilience, Return and, finally, to Reimagination and Reform. The Resolve stage deals with the war against COVID-19, not only on the medical side but also on the business side. After the initial shock, companies need to move the Resilience stage in order to survive what McKinsey (2020b) believes will be the biggest crisis in nearly one century. The Return to normal business is extremely difficult after such a downturn, especially in the supply chain area. Government decisions in this stage are extremely important, as they have to make tough choices with respect to continuing the lockdown measures. Finally, the entire society, including businesses, will have to Reimagine and Reform in order to adapt to the new habits of the consumers. Few trends are obvious, such as the emergence of e-commerce platforms or contactless payments, but others, like supply chain (de)localization are difficult to anticipate. Without any doubt, 
Negrutiu, C., (2021)

Major trends and new business models in supply chain and entrepreneurship after the Covid-19 crisis

technology will play a very important role and it will be a key enabler in the next normal.

The analysts from Kearney, one of the leading European management consulting companies, state very clearly that the word normal is no longer applicable in today's business world (Kearney 2020a). New normal is simply old thinking, with a direct impact on the strategy of the company.

Table 1 Major trends triggered by COVID-19 pandemic

\begin{tabular}{|l|l|l|}
\hline No & \multicolumn{1}{|c|}{ Trend } & \multicolumn{1}{c|}{ Characteristics } \\
\hline 1 & Distance is back & $\begin{array}{l}\text { The old idea of "no borders" is gone. Businesses have to } \\
\text { think now in more local terms, with a direct impact on } \\
\text { supply chains and specific industries, like tourism }\end{array}$ \\
\hline 2 & Resilience AND efficiency & $\begin{array}{l}\text { Resiliency is the ability to absorb a shock that is prepared } \\
\text { in advance of a crisis. Therefore, the companies that had } \\
\text { strong business continuity plans have survived better in } \\
\text { the current crisis also. Supply chains are again a proof of } \\
\text { resiliency and investors have valued considerably better } \\
\text { the companies with resilient supply chains }\end{array}$ \\
\hline 3 & $\begin{array}{l}\text { The rise of the contact-free } \\
\text { economy }\end{array}$ & $\begin{array}{l}\text { The COVID-19 pandemic could prove to be a decisive } \\
\text { turning point for the three peculiar sectors - digital } \\
\text { commerce, telemedicine and automation }\end{array}$ \\
\hline 4 & $\begin{array}{l}\text { More government intervention } \\
\text { in the economy }\end{array}$ & $\begin{array}{l}\text { This is somehow common in all crises, but governments } \\
\text { should be careful with the scope and, especially, the } \\
\text { length of the intervention }\end{array}$ \\
\hline 5 & $\begin{array}{l}\text { More scrutiny for business } \\
\text { As the governments begin to inject money into the } \\
\text { economy, many companies will benefit from these } \\
\text { programs. The public (taxpayers) will be concerned and } \\
\text { have deeper scrutiny on how this money will be sent }\end{array}$ \\
\hline 6 & $\begin{array}{l}\text { Changing industry structures, } \\
\text { consumer behavior, market } \\
\text { positions, and } \\
\text { attractiveness }\end{array}$ & $\begin{array}{l}\text { Some industries will face severe restructuring - e.g. } \\
\text { hospitality will have to adapt to the new social } \\
\text { distancing. Companies will have to adapt or pivot to new } \\
\text { business models }\end{array}$ \\
\hline $\begin{array}{l}\text { Finding the silver linings } \\
\text { Every crisis is also an opportunity for new paradigms. } \\
\text { Some of today's best businesses were born during the } \\
\text { financial crisis of 2008 and its likely that new stars will } \\
\text { be born during the current crisis }\end{array}$ \\
\hline
\end{tabular}

Source: Adapted after McKinsey 2020b

Previously, a 100-day strategy was considered short term, while now a 100-hour strategy may be inadequate. The old mantra of Plan, Make, Source, Deliver has been transformed into Deliver, Source, Make, Plan. The consumer and competitive landscapes have changed so dramatically, so the best strategy, for now, needs to equip the companies "capable of adjusting quite literally to whatever happens next". In a follow-up research, Kearney (2020b) proposes the term of no-normal, as "a period characterized by an intensified sense of immediacy, a permanent now that

88 Sciendo Studia Universitatis "Vasile Goldis" Arad. Economics Series Vol 31 Issue 1/2021 ISSN: 1584-2339; (online) ISSN: $2285-3065$

Web: publicatii.uvvg.ro/index.php/studiaeconomia. Pages 84-96 
Negrutiu, C., (2021)

Major trends and new business models in supply chain and entrepreneurship after the Covid-19 crisis

forces us to live and do business at the moment". Unpredictable analytics is now the only certitude, as the time effectively shrinks, and decisions have to be taken swiftly.

In a global survey, Kearney (2020c) interviewed 80 top executives from the US and 50 from Europe. The main trends revealed that many companies were hit hard, as around $50 \%$ signaled cash problems in the coming six months. On the other hand, businesses showed a high degree of resilience, with about $76 \%$ that was prepared with an emergency plan. Work from home has become the norm for almost $80 \%$ of the employees and almost all the companies transitioned well to the new reality. While operating under Covid-19 conditions, the executives tried to seize new opportunities in order to accelerate change. The main concern highlighted by the companies in the drop-in demand and the (still unknown) consumption patterns. The final trend presented in the survey showed that courageous leaders that assume risks today will likely be the tomorrow winners.

Roland Berger, the largest management consulting company with European roots, addresses the impact of the coronavirus crisis on profitability and liquidity level. Tourism \& travel, airlines and classic retail will be badly hit on both fronts. In contrast, pharma \& medtech will enjoy low to none effects, while logistics and automotive will have short term liquidity issues, but without significant impact on profitability (Roland Berger 2020a).

However, each crisis represents an opportunity for a bright and better future. For example, many historians agree that the Black Death of the $14^{\text {th }}$ century paved the way for Europe to become the global powerhouse that dominated the world for centuries. In more general terms, the magnitude of a crisis it's an indicator of the changes that will come and the opportunity for a quantum leap. The current crisis provides a window of opportunity for change that needs to be seized and implemented. Roland Berger (2020b) proposes a detailed model that is very useful to understand how the crisis can give birth to a new normal. Nevertheless, while the transition process could be similar, the new normal may look different for specific industries. Roland Berger's research cites a few sectors where the transformation will be radical. While in the past e-commerce was just an alternative to classic retail, it is likely that will become the main choice in the future. The same logic applies to meetings and travel, where online will become the norm, and not the exception.

For the transition process to the new normal, Roland Berger (2020a) uses the metaphor of the butterfly effect. The process has four elements, that are distinct for each industry and company - Reboot, Redefine, Reconfigure and Redimension, very similar to the McKinsey approach. The endpoint of the transition is the adaptive organization, which is characterized by enough resiliency, flexibility and elasticity to navigate into the new normal world. 
Negrutiu, C., (2021)

Major trends and new business models in supply chain and entrepreneurship after the Covid-19 crisis

\subsection{Impact of Covid-19 crisis on supply chain and entrepreneurship}

Following the presentation of these global trends, it is worthwhile to deep dive into two major sectors that are impacted heavily by the current crisis: i. Supply chain and ii. Entrepreneurship.

Supply chain recovery is arguably the most significant topic in the post-covid-19 era. Most of the chains were heavily disrupted during the pandemic and, with this, the entire business. How fast and reliable the recovery will be will affect not only the present but also the future. The McKinsey (2020c) research proposes six sets of actions that can enable a resilient supply chain.

Table 2 Supply chain actions in response to pandemic

\begin{tabular}{|c|c|c|}
\hline No & Set & Specific actions \\
\hline 1 & $\begin{array}{l}\text { Create transparency } \\
\text { on multitier supply } \\
\text { chain }\end{array}$ & $\begin{array}{l}\text { Determine critical components and determine the origin of supply } \\
\text { Assess interruption risk and identify likely tier- } 2 \text { and onward risk } \\
\text { Look to alternative sources if suppliers are severely affected } \\
\text { regions }\end{array}$ \\
\hline 2 & $\begin{array}{ll}\text { Optimize } & \text { production } \\
\text { and } & \text { distribution } \\
\text { capacity } & \end{array}$ & $\begin{array}{l}\text { Assess the impact on operations and available resource capacity } \\
\text { (mainly workforce) } \\
\text { Ensure employee safety and clearly communicate with employees } \\
\text { Conduct scenario planning and assess the impact on operations, } \\
\text { based on available capacity } \\
\text { Optimize limited production, according to human-health impact, } \\
\text { margin, and opportunity cost/penalty }\end{array}$ \\
\hline 3 & $\begin{array}{l}\text { Assess realistic } \\
\text { demand for the final } \\
\text { customer }\end{array}$ & $\begin{array}{l}\text { Work with sales and operations planning to get demand signal to } \\
\text { determine the required supply } \\
\text { Leverage direct-to-consumer channels of communication } \\
\text { Use market insights/external databases to estimate for } \\
\text { customer's customers }\end{array}$ \\
\hline 4 & $\begin{array}{l}\text { Estimate available } \\
\text { inventory }\end{array}$ & $\begin{array}{l}\text { Estimate inventory along the value chain, including spare } \\
\text { parts/remanufactured stock } \\
\text { Use after-sales stock as a bridge to keep production running }\end{array}$ \\
\hline 5 & $\begin{array}{l}\text { Identify and secure } \\
\text { logistics capacity }\end{array}$ & $\begin{array}{l}\text { Estimate available logistics capacity } \\
\text { Accelerate customs clearance } \\
\text { Change the mode of transport and prebook air/rail capacity, given } \\
\text { current exposure } \\
\text { Collaborate with all parties to leverage freight capacity jointly }\end{array}$ \\
\hline 6 & $\begin{array}{l}\text { Manage cash and net } \\
\text { working capital }\end{array}$ & $\begin{array}{l}\text { Run supply-chain stress tests vs major suppliers' balance sheets to } \\
\text { understand when supply issues will } \\
\text { start to stress financial or liquidity issues }\end{array}$ \\
\hline
\end{tabular}

Source: Adapted after McKinsey 2020c

The research is continued by Kearney through specific analysis per industry. Most of the findings are similar to McKinsey's, emphasizing the need for a completely digital transformation of the business. Kearney (2020d) highlights 5 core areas in 
Negrutiu, C., (2021)

Major trends and new business models in supply chain and entrepreneurship after the Covid-19 crisis

which top management should focus: Automation, AI, and cybersecurity, Mobile and e-commerce, Supplier performance and risk, Workforce management, and Cost optimization. The supply chain is another area that will see a profound transformation, especially in the last mile delivery. This trend was perceived also previously, but the new health crisis and the rise of e-commerce have put supply chains under extreme pressure. End-to-end visibility and on-time delivery have to be matched with flexibility and resilience, all of this ensuring the lowest possible cost per package. An extra factor complexity is added when in the food and grocery supply chains, that really exploded during the crisis. People that ordered online their bare necessities instead of going to their convenience store will likely repeat this habit in the future. Digitization and omnichannel strategies have to be adopted in order to pivot the supply chain in the new era. A summary of the key changes in the supply chain set-up is summarized in Table 3.

Table 3 Supply chain key changes

\begin{tabular}{|l|l|}
\hline Key change & \multicolumn{1}{c|}{ Actions } \\
suarcing & $\begin{array}{l}\text { Consistent multi-sourcing across regions/continents to decrease exposure to single } \\
\text { regions (both supplier base and manufacturing sites) } \\
\text { Consistent second source qualification in registration dossiers } \\
\text { IP ownership for component designs and production processes as much as possible } \\
\text { to be able to switch suppliers or shift to CMO models }\end{array}$ \\
\hline $\begin{array}{l}\text { Reduced } \\
\text { complexity }\end{array}$ & $\begin{array}{l}\text { Reduce the global span of the supply chain by focusing the supply chain on a select } \\
\text { set of regions } \\
\text { Insource core business priorities such as battery production in automotive }\end{array}$ \\
\hline Localizing & $\begin{array}{c}\text { Increase the use of local suppliers and manufacturing capacities to: } \\
\text { decrease exposure to increasing transportation costs in case of disruption } \\
\text { decrease exposure to global trade flow disruptions triggered by trade } \\
\text { tensions or crises such as COVID-19 } \\
\text { allow for lower safety stocks allowing for quicker pivoting in times of } \\
\text { disruptions }\end{array}$ \\
\hline
\end{tabular}

Source: Adapted after Kearney 2020e

The McKinsey research concludes with the private equity/venture capital sector (McKinsey 2020d). The specific of this industry is to be trend and talent spotter, as the funds invest in new and bold ideas in hope of a good return. Therefore, the start-ups in which PE/VC invested during and after the crisis will be a good indicator of what the future may look like. As regards the current portfolio of invested companies, the main concern of the fund managers is financial and liquidity risk. It is often said that cash is king, but for start-ups, this is of utmost importance. These companies have usually negative cash flows, as they are in a development phase, so they need the support of their PE/VC. Collaboration is key here between founders and fund managers; McKinsey proposes the establishment 
Negrutiu, C., (2021)

Major trends and new business models in supply chain and entrepreneurship after the Covid-19 crisis

of a common "cash war room". After the mitigation of cash risks, the other risks must be taken into consideration, starting with the risks to employees' and customers' health, safety, and productivity. Most of the start-ups have very small teams and the illness of one member can put in danger the operations of the entire company. The other risks have to be carefully assessed, from short term to long term, as well as less tangible risks. The company strategy needs to be re-visit in the end with open eyes, a start-up is a flexible organization that can adapt easily to the new reality.

Last, but not least, the PE/VC sector must learn some lessons from the last crisis of 2008. The first one is value creation and portfolio expansion during the crisis. Very often, a crisis is an opportunity to close good deals, as a fund can buy at lower valuations than normal. A study performed by McKinsey 2020d showed that general partners with value-creation teams produced higher returns during the last recession and raised more capital afterward. Another conclusion of the study is those general partners that were more acquisitive during the recession performed better and raised more capital. In a nutshell, courageous and bold fund managers that were not scared in a crisis had better results not only in a short term but also long term by attracting new funds from investors.

\subsection{Future business models}

While supply chain is probably the most affected sector during the current crisis, technology (actually the acceleration of it...) is for sure the biggest gainer. Previously, it took many months/years for a company to prepare a digital transformation strategy. Now, companies and other institutions (e.g. universities) had to deploy new technologies and tools in a matter of days to ensure business continuity. For sure, the future will be digital and those who cannot adapt and adopt a tech attitude will simply get out of business.

The breadth and depth of the digital transformation will reinvent the core business model for many companies. More specifically, it is expected to see a complete change in a few critical areas of the business, such as supply chain transparency and flexibility, data security, and remote workforce and automation. This overnight digital transformation and re-engineering of the company will drive, according to McKinsey 2020c, six types of business models. 
Negrutiu, C., (2021)

Major trends and new business models in supply chain and entrepreneurship after the Covid-19 crisis

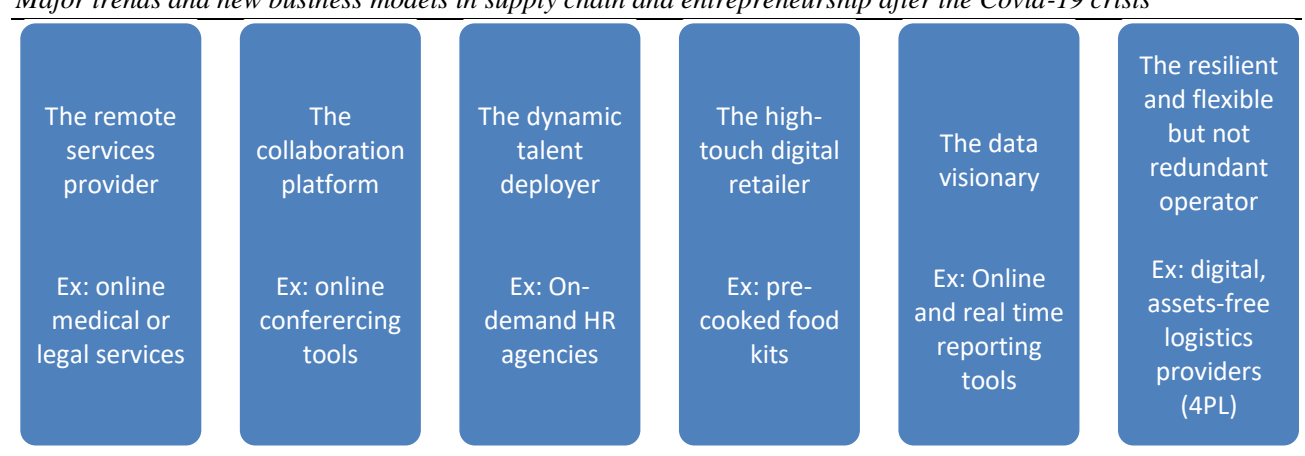

Figure 1 Business models in the post-pandemic world Adapted after McKinsey 2020c

In the author's opinion, business models of the future and, in particular, the supply chain will have to be built in a virtuous cycle, where all the elements are mutually fueled by each other, as depicted in Figure 2.

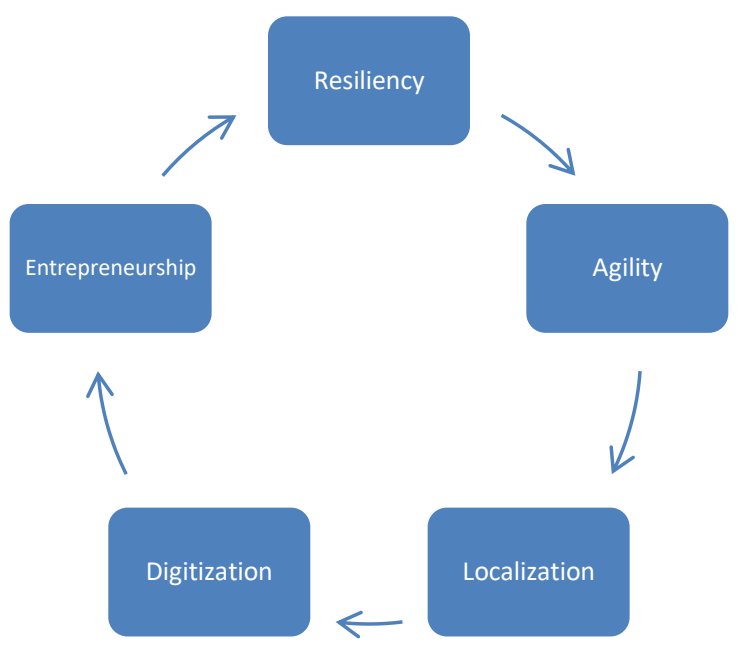

Figure 2 The virtuous cycle of future elements of business models in supply chain Source: author's view

\section{Conclusions, limitations and future research}

The present paper addressed a topic that is yet to be understood for academia and practice. The current health crisis is not over and it's likely to continue in the near future. People and businesses have to adapt to the new reality helped by the research done during this period, but the truth is that nobody knows how the future will look like. 
Negrutiu, C., (2021)

Major trends and new business models in supply chain and entrepreneurship after the Covid-19 crisis

Nevertheless, the analysis of the studies done by the top management consulting companies revealed some similarities and common trends. All of them agree that the future is not only digital but also that the current crisis provided an excellent opportunity to speed up the implementation of a true digital strategy. Another common topic is a supply chain that is now facing unseen challenges, being at the same time critical for the survival of the company. The supply chain will probably be one of the biggest areas in terms of the magnitude of change, as virtually all the companies are re-thinking their strategy and set-up. Resiliency and flexibility have to be embedded in all processes and especially in the strategies of the companies. The usual long-term plan is a matter of the past and change is likely to become the only constant in the life of a business. Last, but not least, this is the time for courage and new endeavors that will capture the new reality and transform it into viable businesses. The best companies of tomorrow may be born during these days. The present research has some limitations due, first of all, to objective reasons. The scientific literature on the crisis in general is very extensive, making virtually impossible a thorough literature review. On the other hand, the research on the implications of Covid 19 has just started. Therefore, the author selected the research of the top management consultants, but the selection of these companies is naturally subjective, although all of them are reputable names. The author wishes to continue the research by focusing on the areas of supply chain and entrepreneurship through case studies and quantitative analysis.

\section{Acknowledgments}

The author thanks the anonymous reviewers and editor for their valuable contribution.

\section{Funding}

This research received no external funding.

\section{Author Contributions}

The entire article was written by Cristian Negrutiu.

\section{Disclosure Statement}

The author declares no conflict of interest

\section{References}

1. Brătianu, C., 2020, Sustainability risk management of firms, Amfiteatru Economic, 22 (55), pp. 635-637.

2. Ciocoiu, C.N., Prioteasa, A.L., Colesca, S.E., 2020, Risk Management Implementation for Sustainable Development of Romanian SMEs: A Fuzzy Approach, Amfiteatru Economic, 22(55), pp. 726-741. 
Negrutiu, C., (2021)

Major trends and new business models in supply chain and entrepreneurship after the Covid-19 crisis

3. Hermann, C.F., Some consequences of crisis which limit the viability of organizations, Adm. Sci. Q. 1963, 8, 61-82

4. Kearney, 2020a, New normal? Old thinking!, available at https://www.kearney .com/covid-19/article/?/a/new-normal-old-thinking, accessed on [03 July 2020]

5. Kearney, 2020b, No normal, available at https://www.kearney.com/no-normal, accessed on 04 July 2020

6. Kearney, 2020c, Impact magazine: Issue no 5, 7 May 2020, available at https: //www.kearney.com/documents/20152/10957260/Impact_Eng_\%235_FINAL.pdf, accessed on 05 July 2020

7. Kearney, 2020d, Impact magazine: Issue no 6, 15 May 2020, available at https: //www.kearney.com/documents/20152/12692025/impact_UK_\%236.pdf/3c3a32af-1766-

3128-67f1-fce46b07cfd3?t=1589538691399, accessed on 06 July 2020

8. Kearney, 2020e, Impact magazine: Issue no 7, 22 May 2020, available at https://www.kearney.com/documents/20152/14010714/impact_ENG_\%237_220520_2_lo w.pdf/1bb287a8-e54f-c76e-74c7-86430e7a8477?t=1590140455722, accessed on 06 July 2020

9. Maritz, A., Perenyi, A., de Waal, G., Buck, C. 2020, Entrepreneurship as the Unsung Hero during the Current Covid-19 Economic Crisis: Australian Perspectives, Sustainability, vol. 12, no. 11, pp. 4612.

10. Mitroff, I.I. Crisis management: Cutting through the confusion, MIT Sloan Manag. Rev. 1988, 29, 15.

11. McKinsey, 2020a, The path to the next normal, available at https: //www.mckinsey.com/featured-insights/coronavirus-leading-through-the-crisis/ navigatingto-the-next-normal-the-first-100-insights, accessed on 11 July 2020

12. McKinsey, 2020b, Safeguarding lives and livelihoods, available at https: //www.mckinsey.com/featured-insights/coronavirus-leading-through-the-crisis /navigatingto-the-next-normal-the-first-100-insights, accessed on 12 July 2020

13. McKinsey, 2020c, Getting back to work, available at https: //www.mckinsey.com/featured-insights/coronavirus-leading-through-the-crisis/ navigatingto-the-next-normal-the-first-100-insights, accessed on 13 July 2020

14. McKinsey, 2020d, Jumpstarting the recovery, available at https: //www.mckinsey.com/featured-insights/coronavirus-leading-through-the-crisis/ navigatingto-the-next-normal-the-first-100-insights, accessed on 14 July 2020

15. Obrenovic, B., Du, J., Godinic, D., Tsoy, D., Muhammad Aamir, S.K., Jakhongirov, I., 2020, Sustaining Enterprise Operations and Productivity during the Covid-19 Pandemic: Enterprise Effectiveness and Sustainability Model, Sustainability, vol. 12, no. 15, pp. 5981. 16. Pató, B.S., Herczeg, M., 2020, The effect of the Covid-19 on the automotive supply chains, Studia Universitatis Babes-Bolyai, vol. 65, no. 2, pp. 1-11.

17. Pelău, C., Ene, I., 2020, Interaction between consumers and emerging forms of artificial intelligence: a discriminant analysis, Studia Universitatis "Vasile Goldis" Arad. Economics Series Vol 30 Special Issue 2/2020 ISSN: 1584-2339; (online) ISSN: 2285 3065

18. Rashad, W., Nedelko, Z., 2020, Global Sourcing Strategies: A Framework for Lean, Agile, and Leagile, Sustainability, vol. 12, no. 17, pp. 7199. 
Negrutiu, C., (2021)

Major trends and new business models in supply chain and entrepreneurship after the Covid-19 crisis

19. Roland Berger, 2020a, The Butterfly Principle, available at https: //www.rolandberger.com/en/Point-of-View/The-Butterfly-Principle.html, accessed on 15 July 2020

20. Roland Berger, 2020b, Sailing on uncharted waters, available at https: //www.rolandberger.com/en/Publications/Growth-growth-growth.html, accessed on 18 July 2020

21. Tecău, A.S., Constantin, C.P., Lixăndroi, R.C., Chiţu, I.B., Brătucu, G. 2020, Impact of the Covid-19 crisis on heavy work investment in Romania, Amfiteatru Economic, vol. 22, no. 14, pp. 1049-1067. 